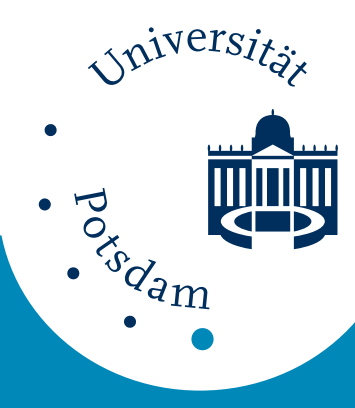

Universität Potsdam

Helmut Elsenbeer, Adam West, Mike Bonell

\title{
Hydrologic pathways and stormflow hydrochemistry at South Creek, northeast Queensland
}

first published in:

Journal of Hydrology. - 126 (1994), 1-2, p. 1 - 21

ISSN: 0022-1694

DOI: $10.1016 / 0022-1694(94) 90002-7$

Postprint published at the institutional repository of Potsdam University:

In: Postprints der Universität Potsdam :

Mathematisch-Naturwissenschaftliche Reihe ; 46

http://opus.kobv.de/ubp/volltexte/2008/1690/

http://nbn-resolving.de/urn:nbn:de:kobv:517-opus-16904

Postprints der Universität Potsdam

Mathematisch-Naturwissenschaftliche Reihe ; 46 


\title{
Hydrologic pathways and stormflow hydrochemistry at South Creek, northeast Queensland
}

\author{
Helmut Elsenbeer ${ }^{\mathrm{a}, *}$, Adam West ${ }^{\mathrm{b}}$, Mike Bonell ${ }^{\mathrm{b}}$ \\ anstitute of Geography, University of Berne, Hallerstr. 12, 3012 Berne, Switzerland \\ ${ }^{b}$ Department of Geography, James Cook University, Townsville Qld. 4811, Australia
}

Received 4 October 1993; revision accepted 11 April 1994

\begin{abstract}
Earlier investigations at South Creek in northeastern Queensland established the importance of overland flow as a hydrologic pathway in this tropical rainforest environment. Since this pathway is 'fast', transmitting presumably 'new' water, its importance should be reflected in the stormflow chemistry of South Creek: the greater the volumentric contribution to the stormflow hydrograph, the more similarity between the chemical composition of streamwater and of overland flow is to be expected. Water samples were taken during two storm events in an ephemeral gully (gully A), an intermittent gully (gully B) and at the South Creek catchment outlet; additional spot checks were made in several poorly defined rills. The chemical composition of 'old' water was determined from 45 baseflow samples collected throughout February. The two events differed considerably in their magnitudes, intensities and antecedent moisture conditions. In both events, the stormflow chemistry in South Creek was characterized by a sharp decrease in $\mathrm{Ca}, \mathrm{Mg}, \mathrm{Na}, \mathrm{Si}, \mathrm{Cl}, \mathrm{EC}, \mathrm{ANC}$, alkalinity and total inorganic carbon. $\mathrm{pH}$ remained nearly constant with discharge, whereas $\mathrm{K}$ increased sharply, as did sulfate in an illdefined manner.

In event 1 , this South Creek stormflow pattern was closely matched by the pattern in gully A, implying a dominant contribution of 'new' water. This match was confirmed by the spot samples from rills. Gully B behaved like South Creek itself, but with a dampened 'new' water signal, indicating less overland flow generation in its subcatchment. In event 2 , which occurred five days later, the initial 'new' water signal in gully $A$ was rapidly overwhelmed by a different signal which is attributed to rapid drainage from a perched water table.

This study shows that stormflow in this rainforest catchment consists predominantly of 'new' water which reaches the stream channel via 'fast' pathways. Where the ephemeral gullies delivering overland flow are incised deeply enough to intersect a perched water table, a delayed, 'old' water-like signal may be transmitted.
\end{abstract}

\footnotetext{
* Corresponding author.
}

0022-1694/94/\$07.00 (C) 1994 - Elsevier Science B.V. All rights reserved SSDI 0022-1694(94)02522-D 


\section{Introduction}

Pronounced changes in streamwater chemistry during storm events have been documented for a variety of ecosystems (e.g. Jenkins, 1989; Mulder et al., 1990; Mulholland et al., 1990; Muscutt et al., 1990; Wels et al., 1991; Avila et al., 1992; Giusti and Neal, 1993; Whitfield et al., 1993). Since a major incentive for such studies stems from the need to assess and to predict the impact of acidification on ecosystems, a geographical bias towards ecosystems in northern Europe and eastern North America has been unavoidable. Similar studies from equatorial regions have not been published.

Few studies have explicitly coupled episodic changes in stormflow chemistry with an investigation of hydrological pathways (Muscutt et al., 1990; Wilson et al., 1991a, b; Hill 1993); rather, pathways were inferred from changes in stormflow chemistry. This approach is valid if a priori knowledge about the behavior of the chemical species under consideration is available (Beck et al., 1990). Alternatively, a coupling between catchment hydrology and hydrochemistry can be achieved if a priori hydrological knowledge is available, i.e. the stormflow hydrochemistry of a catchment can be explained in terms of hydrological pathways which have been determined independently.

In the case of the South Creek catchment in northeast Queensland, overland flow was established as a dominant hydrological pathway (Bonell and Gilmour, 1978); it was explained as the consequence of the interaction between rainfall variables and soil hydraulic properties (Bonell et al., 1981). In terms of the 'new' vs. 'old' water controversy, a 'fast' pathway such as overland flow delivering 'new' water to the stream provides a basis for linking between catchment hydrology and hydrochemistry. This coupling will be strengthened by a priori assumptions concerning the conservative nature of some of the chemical species under consideration. In a previous study in western Amazonia (Elsenbeer and Cassel, 1989), the chemical composition of overland flow was shown to change through an event. If this were observed elsewhere, in a geo-ecosystem where overland is an important pathway, a simple mixing of 'old' and 'new' water would not suffice to explain stormflow chemographs; rather, such chemographs would also reflect the temporal variation of 'new' water.

This paper presents the results of an integrated hydrochemical investigation of a tropical rainforest catchment to explain episodic changes in stormflow chemistry in terms of known hydrologic flowpaths. The emphasis here is on short-term, within event variations of the solute chemistry of surficial waters including overland flow itself.

\section{Study area}

The South Creek catchment has an area of $25.7 \mathrm{ha}$, ranging in elevation from about $25 \mathrm{~m}$ to $190 \mathrm{~m}$ a.m.s.l. It is located at $17^{\circ} 20^{\prime} \mathrm{S}$ and $145^{\circ} 58^{\prime} \mathrm{E}$ in the Graham Range near the Queensland coast. The 1985-1992 mean annual precipitation at Babinda, about 
$5 \mathrm{~km}$ west of the catchment, is $4241 \mathrm{~mm}$; the mean and 1993 February precipitation levels are $733 \mathrm{~mm}$ and $540 \mathrm{~mm}$, respectively.

The drainage network is displayed in Fig. 1. The majority of the streams depicted are actually gullies, rills, or concentrated-flow lines without a defined channel, active only in response to precipitation events. Very few gullies, such as the intermittent gully B, maintain flow in the wet and early dry season. Gully A, although incised, flows only in response to rainfall events.

Three soil profiles were described (see Fig. 1); P1 and P2 were classified as Inceptisols, P3 as Oxisol. The former are located on a steep sideslope, the latter on near-level terrain. In the absence of a catchment-wide soil survey, knowledge of the catchment topography suggests that Oxisols occupy only a minor portion of the catchment whereas Inceptisols are dominant with respect to areal coverage. The depth to weathered bedrock increases with distance from the stream channel; in the case of soil profile P3, this depth is greater than $3 \mathrm{~m}$. The catchment lithology is dominated by amphibolite; ortho-amphibolite outcrops along the channel of South Creek consist of andesine, sodic luminous hornblende, quartz, chromiumrich chlorite, actinolite, epidote and some opaques. Detailed information on lithology, geochemistry and pedology will be published elsewhere, but details of soil physical properties, vegetation, hydrology and climatology have already been published (Bonell and Gilmour, 1978, 1980; Bonell et al., 1981; Bonell et al., 1991).

\section{Methods}

Stream discharge was monitored continuously at a permanent gauging station at South Creek equipped with a V-notch weir.

During the study period from 29 January to 25 February 1993, grab samples were taken, daily, initially and from 6 February on twice a day, from South Creek at the gauging station, and from gully B near its confluence with South Creek, to determine the background chemical signal. During the rainfall events of 18 and 23 February, frequent grab samples were taken from South Creek and from gully $\mathrm{B}$, as well as from gully $\mathrm{A}$ which was active during those events. The sampling sites of South Creek, gully A, and gully B are situated within about $50 \mathrm{~m}$. Grab samples were collected in preference to using an auto-sampler to ensure rapid sample processing.

Polyethylene bottles $(1 \mathrm{~L})$ were rinsed three times with the respective waters before a sample was taken. The maximum time lapse between sampling the stream and the gullies was $2 \mathrm{~min}$. The samples can therefore be regarded as synchronous. Temperature and electrical conductivity were determined immediately, until a probe failure occurred during the first event. $\mathrm{pH}$ measurements, fixed-endpoint and Gran titrations to determine alkalinity and total inorganic carbon were completed within $20 \mathrm{~min}$ of the routine sampling, and within no more than $1 \mathrm{~h}$ during the event sampling. Complete filling of sample bottles and tight sealing were assumed to reduce the gas exchange between the sample and the atmosphere. 



Fig. 1. The South Creek research catchment in northeastern Queensland with sampling sites and locations of soil profiles $\mathrm{P} 1, \mathrm{P} 2$ and $\mathrm{P} 3$. 
Unfiltered subsamples for later laboratory analyses at the Australian Centre for Tropical Freshwater Research were refrigerated within $5 \mathrm{~min}$ of sampling. In these subsamples, silica was determined spectrophotometrically, sulfate turbidimetrically, chloride argentometrically, and calcium, magnesium, sodium and potassium with atomic absorption spectrophotometry (AAS); all methods followed the guidelines of APHA (1989).

\section{Results and discussion}

\subsection{Streamwater chemistry}

Table 1 provides some descriptive statistics of the baseflow chemistry. The background levels between events vary around $5.5 \mathrm{ppm}$ for $\mathrm{Ca}$, around $4.2 \mathrm{ppm}$ for $\mathrm{Mg}$, around $5.7 \mathrm{ppm}$ for $\mathrm{Na}$, and around $0.19 \mathrm{ppm}$ (near the detection limit) for $\mathrm{K}$. The last named shows considerable variation. The background concentration of $\mathrm{SiO}_{2}$ is near $13.1 \mathrm{ppm}$. Baseflow electric conductivity (EC) averages $84.8 \mu \mathrm{S} \mathrm{cm}^{-1}$ and its $\mathrm{pH}$ is near-neutral.

Total inorganic carbon averages $0.75 \mathrm{mmol} \mathrm{L}^{-1}$, alkalinity and acid-neutralizing capacity (ANC) 0.67 and $0.57 \mathrm{meq}^{-1}$, respectively.

The anions are both characterized by a high coefficient of variation; the medians of chloride and sulfate are 7.2 and $3.1 \mathrm{ppm}$, respectively. In the following, the changes in streamflow and overland flow chemistry during events one and two are examined in detail.

Table 1

South Creek baseflow chemistry (Units are in ppm except where noted)

\begin{tabular}{lcccccc}
\hline Quantity & $\mathrm{N}^{\mathrm{a}}$ & Mean & $\mathrm{CV}^{\mathrm{a}}$ & $75 \% \mathrm{Q}^{\mathrm{a}}$ & Median & $25 \% \mathrm{Q}^{\mathrm{a}}$ \\
\hline $\mathrm{Ca}$ & 45 & 5.2 & 18.7 & 5.7 & 5.5 & 4.9 \\
$\mathrm{Mg}$ & 45 & 4.1 & 19.4 & 4.5 & 4.2 & 3.7 \\
$\mathrm{Na}$ & 45 & 5.6 & 16.6 & 6.1 & 5.7 & 5.2 \\
$\mathrm{~K}$ & 45 & 0.21 & 65.2 & 0.25 & 0.19 & 0.15 \\
$\mathrm{SiO}_{2}{ }^{\mathrm{b}}$ & 45 & 13.1 & 16.4 & 14.2 & 13.1 & 12.5 \\
$\mathrm{EC}^{\mathrm{c}}$ & 51 & 84.6 & 21.6 & 99.0 & 84.8 & 73.7 \\
pH $^{\text {d }}$ & 53 & 7.3 & 1.7 & 7.3 & 7.3 & 7.2 \\
Total C$^{\mathrm{b}}$ & 48 & 0.74 & 19.2 & 0.81 & 0.75 & 0.69 \\
Alkalinity & 48 & 0.65 & 14.7 & 0.71 & 0.67 & 0.60 \\
ANC & 45 & 0.55 & 26.6 & 0.65 & 0.57 & 0.48 \\
Cl & 45 & 7.6 & 54.4 & 7.7 & 7.2 & 6.8 \\
Sulfate & 45 & 3.4 & 69.1 & 4.4 & 3.1 & 1.6 \\
\hline
\end{tabular}

${ }^{a} \mathrm{~N}=$ sample size, $\mathrm{CV}=$ coefficient of variation, $75 \% \mathrm{Q}=$ upper quartile, $25 \% \mathrm{Q}=$ lower quartile.

b Unit: $\mathrm{mmol} \mathrm{L}^{-1}$.

' Unit: $\mu \mathrm{S} \mathrm{cm}^{-1}$.

${ }^{d}$ Unit: $\mathrm{pH}$ units.

c Unit: meq $\mathrm{L}^{-1}$. 
Table 2

Selected hydrometeorologic characteristics of the two events

\begin{tabular}{lcc}
\hline Rainfall variable & Event 1 & Event 2 \\
\hline Magnitude $(\mathrm{mm})$ & 177.7 & 44.2 \\
Duration $(\mathrm{h})$ & 18.1 & 3.0 \\
$\mathrm{I}_{6} \max ^{\mathrm{a}}\left(\mathrm{mm} \mathrm{h}^{-1}\right)$ & 90.0 & 63.0 \\
$\mathrm{I}_{10} \max \left(\mathrm{mm} \mathrm{h}^{-1}\right)$ & 79.8 & 60.0 \\
$\mathrm{I}_{30} \max \left(\mathrm{mm} \mathrm{h}^{-1}\right)$ & 57.6 & 45.0 \\
$\mathrm{I}_{60} \max \left(\mathrm{mm} \mathrm{h}^{-1}\right)$ & 50.7 & 27.8 \\
$\mathrm{I}_{120} \max \left(\mathrm{mm} \mathrm{h}^{-1}\right)$ & 45.5 & 17.5 \\
\hline
\end{tabular}

a These are maximum intensities, with the subscripts referring to the time period in minutes over which they were evaluated.

\subsection{Event $1-18$ February $1993,177.7 \mathrm{~mm}$ rain in $18.1 \mathrm{~h}$, no previous rainfall for 14 days}

The hydrograph of this event (see Table 2 for rainfall details) is double-peaked, with the two peaks occurring within $1 \mathrm{~h}$. Although the sampling scheme yielded changes in ion concentrations between the two peaks, these changes were minor compared to those during the hydrograph recession. Therefore, event 1 is treated as a single-peak event.

Fig. 2 displays the inverse relationship between discharge and the concentration of $\mathrm{Ca}, \mathrm{Mg}$ and $\mathrm{Na}$, as well as $\mathrm{SiO}_{2}$. This effect is well documented for a variety of geo-ecosystems (e.g. Feller and Kimmins, 1979; Harriman et al., 1990; Avila et al., 1992; Hill, 1993; Giusti and Neal, 1993), although its occurrence may depend on antecedent moisture conditions (Muscutt et al., 1990; Avila et al., 1992). The behavior of these species in South Creek mirrors closely that in gully A, which contributes mainly 'new' water to the stormflow hydrograph. The high concentrations of these species at the onset of overland flow may be attributed to a flushing effect, i.e. a limited reservoir, such as the litter layer, releases these species rapidly. Alternatively, if the reservoir is not limited, but releases these species at a lower rate, the dilution increases with the depth of overland flow. Either way, the lowest concentrations of $\mathrm{Ca}, \mathrm{Mg}, \mathrm{Na}$ and $\mathrm{SiO}_{2}$ in South Creek are similar to those in gully $\mathrm{A}$. During the recession and until overland flow ceases, the concentrations in gully A are consistently higher than in South Creek. Gully B has a composition which resembles baseflow chemistry in South Creek between events. It contributes stormflow water diluted with respect to the pre-event $\mathrm{Ca}, \mathrm{Mg}, \mathrm{Na}$ and $\mathrm{SiO}_{2}$ concentrations. Although its lowest levels are noticeably higher than the corresponding levels in South Creek, the subcatchment of gully B mirrors South Creek, but produces proportionately less overland flow than the South Creek catchment as a whole.

Fig. 3 depicts a roughly ten-fold increase in $\mathrm{K}$ concentration with discharge at South Creek; with a smaller increase in gully $\mathrm{B}$. This result is consistent with the above interpretation that the subcatchment of gully B produces less overland flow. 



Gully 8

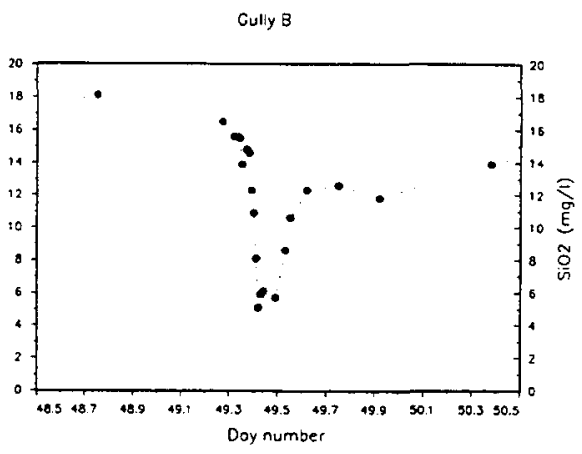

South Creek

South Creek
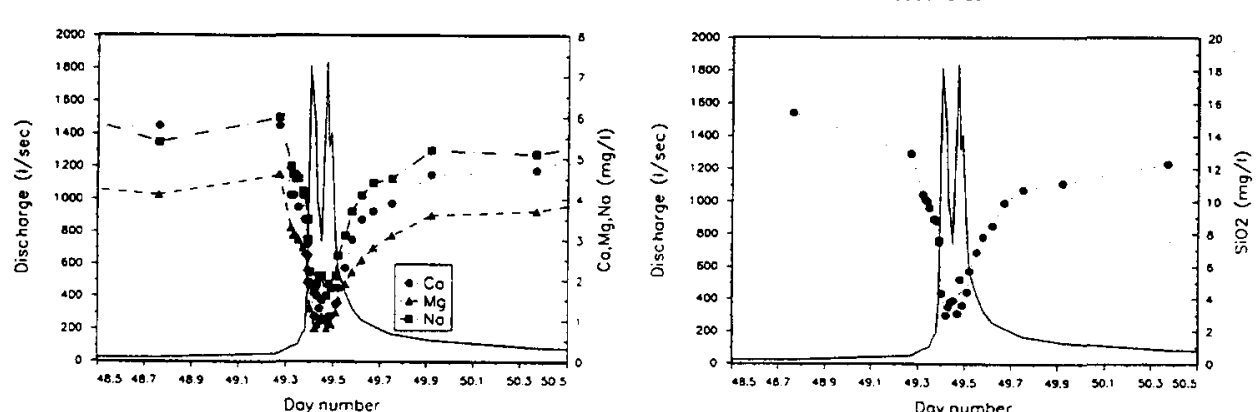

Fig. 2. South Creek discharge (solid line, bottom), and calcium, magnesium, sodium and silica concentrations in gully A (top), gully B (middle) and South Creek (bottom) during event 1. The open symbol in the top panels represents the mean concentration of gullies $\mathrm{C}, \mathrm{D}$ and $\mathrm{E}$.

The assumption underlying this interpretation, of course, is that overland flow is the dominant, if not the only, contributor of $\mathrm{K}$ to stream stormflow. The $\mathrm{K}$ concentration in gully A decreases initially, as the depth of overland flow increases, which is consistent with a flushing effect. Then, unlike the other elements considered so far and similar to South Creek, a quite distinct peak occurs. The positive correlation between discharge and $\mathrm{K}$ concentration during stormflow, albeit possibly dependent on antecedent moisture conditions, has been documented for other regions (e.g. Miller and Drever, 1977; Muscutt et al., 1990; Avila et al., 1992; Giusti and Neal, 

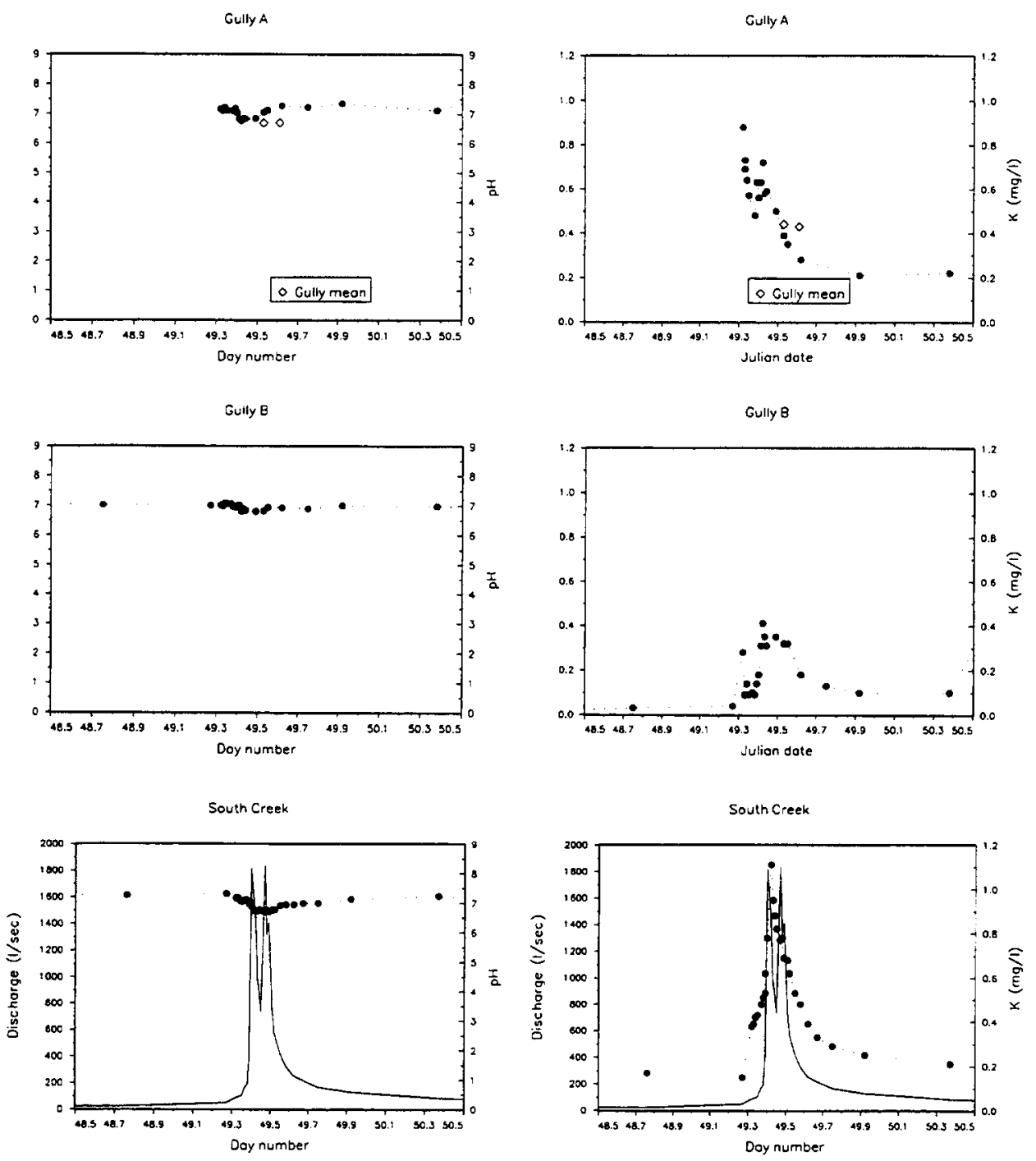

Fig. 3. South Creek discharge (solid line, bottom), and $\mathrm{pH}$ and potassium concentration in gully $\mathrm{A}$ (top), gully B (middle) and South Creek (bottom) during event 1.

1993, Hill, 1993). Whether such stormflow K patterns are in all cases solely due to overland flow cannot be established without an adequate sampling approach; nonetheless, the evidence provided by Muscutt et al. (1990) tends to support this proposition, whereas Hill's (1993) data are inconclusive in this respect. The results presented definitely point to overland flow as a vector for $\mathrm{K}$.

Fig. 3 also shows that the depression in $\mathrm{pH}$ associated with stormflow is less than one unit in South Creek. The $\mathrm{pH}$ change is similar in gully $\mathrm{A}$, and hardly detectable in gully $\mathrm{B}$; as may be expected from the remoteness of this location from potential sources of air pollution, there is no acid deposition which may result in a pronounced 
Gully A



Gully B

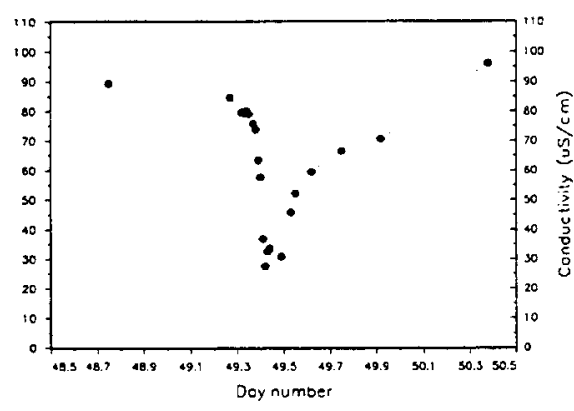

South Creek

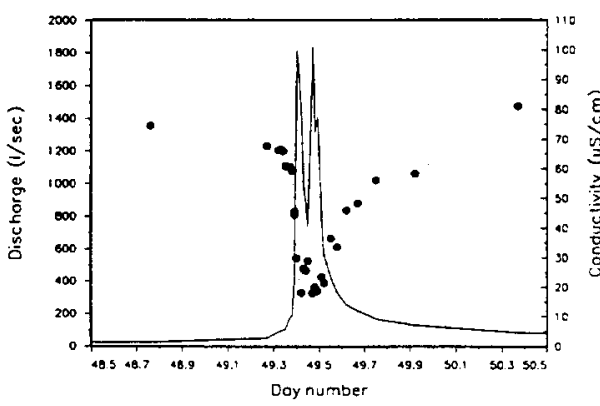

GullyA

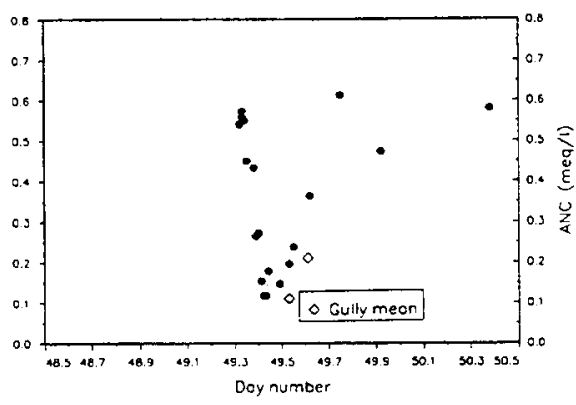

Gully 8

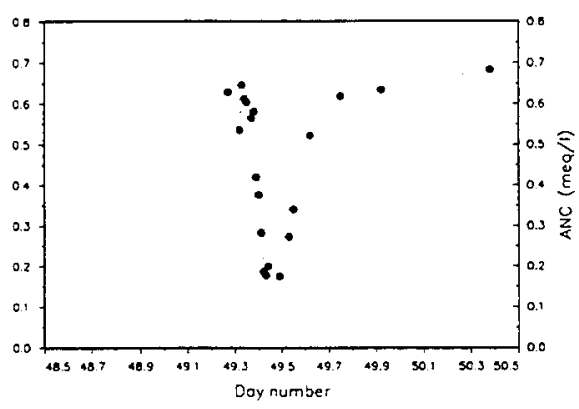

South Creek

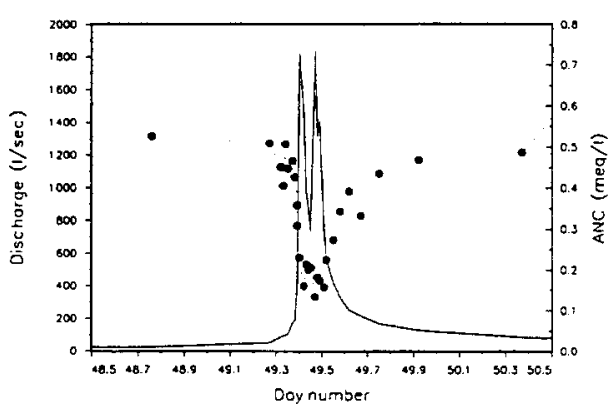

Fig. 4. South Creek discharge (solid line, bottom), and electric conductivity and acid neutralizing capacity in gully A (top), gully B (middle) and South Creek (bottom) during event 1 . The open symbol in the top panels represents the mean value of gullies $C, D$ and $E$.

$\mathrm{pH}$ depression during an event. Periodic checks of rain $\mathrm{pH}$ confirmed that the $\mathrm{H}_{2} \mathrm{O}-\mathrm{CO}_{2}$ buffering system alone explains the observed values. The stormflow $\mathrm{pH}$ depression is comparable to those reported by Avila et al. (1992) for a Mediterranean geo-ecosystem, and by Whitfield et al. (1993) for a maritime temperate forest environment.

Values of EC and ANC (Fig. 4), as well as alkalinity and total inorganic carbon (Fig. 5) are inversely related to discharge in a manner similar to $\mathrm{Ca}, \mathrm{Mg}, \mathrm{Na}$ and $\mathrm{SiO}_{2}$. This similarity, of course, reflects the fact that EC and ANC are codetermined by $\mathrm{Ca}$, 

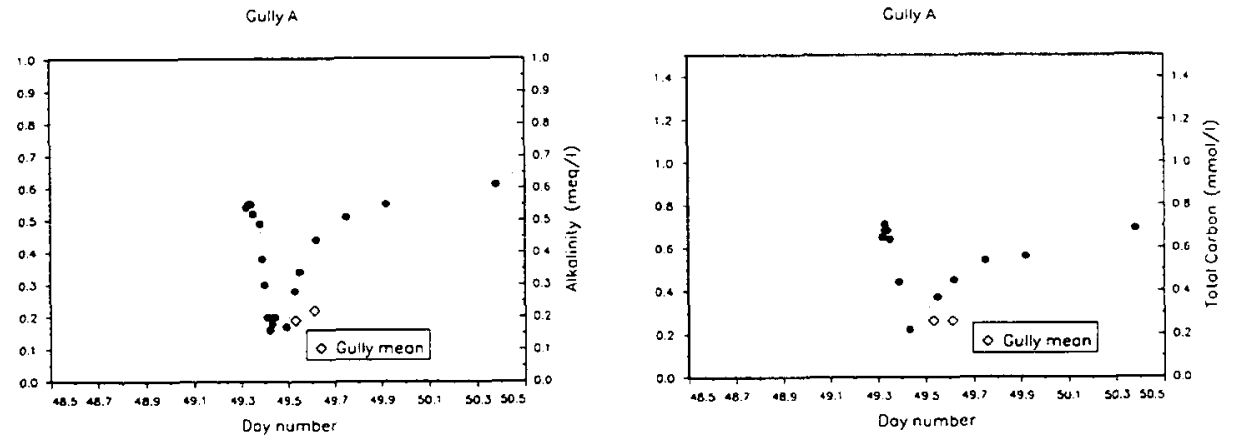

Gully a

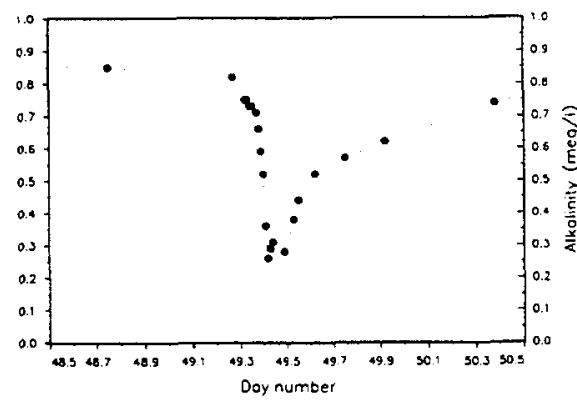

Gully $B$

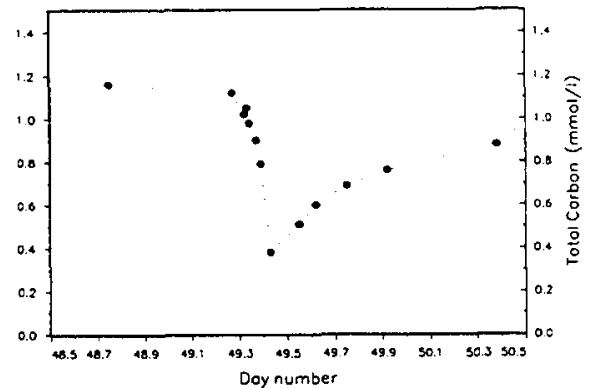

South Creek
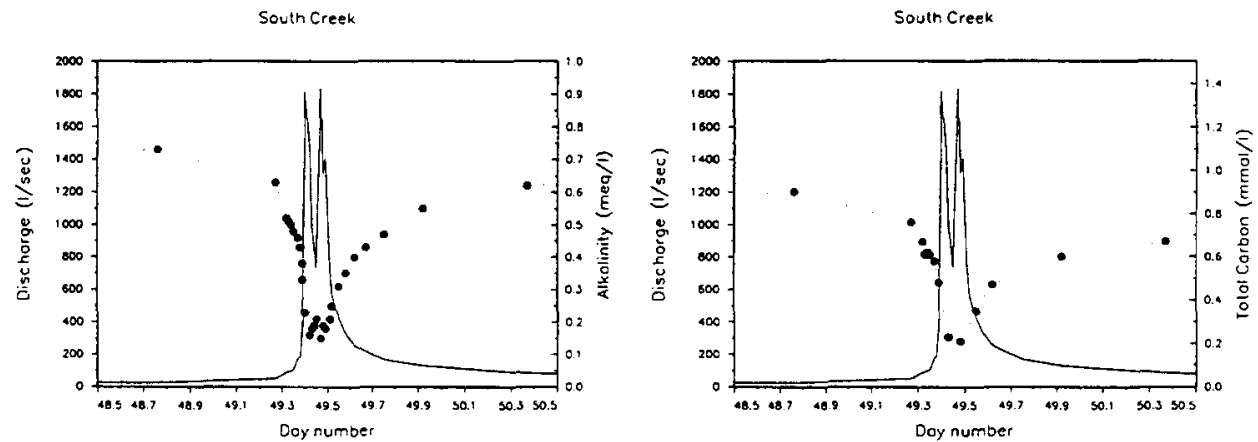

Fig. 5. South Creek discharge (solid line, bottom), and alkalinity and total inorganic carbon concentration in gully A (top), gully B (middle) and South Creek (bottom) during event 1 . The open symbol in the top panels represents the mean value of gullies $C, D$ and $E$.

$\mathrm{Mg}$ and $\mathrm{Na}$, either by way of measurement (EC) or calculation (ANC). As before, the respective lowest levels in South Creek and gully $A$ are nearly identical, while the corresponding levels in gully B are consistently higher. The observed EC pattern in South Creek contrasts with studies which reported a positive correlation between EC and discharge (e.g. Robson et al., 1992); this may reflect differences in rainfall chemistry at the two sites. The observed decrease in ANC, or alkalinity, is consistent with results from elsewhere, regardless of the occurrence of acid deposition (e.g. Avila et al., 1992; Whitfield et al., 1993). 
Gully A

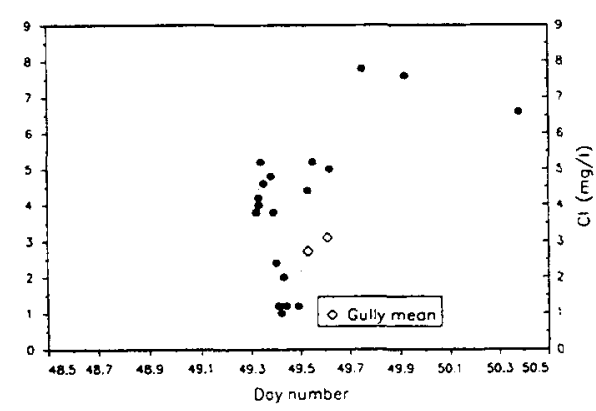

Guilye

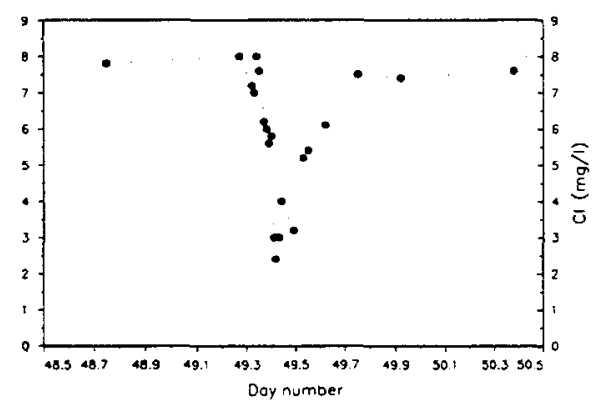

South Creek

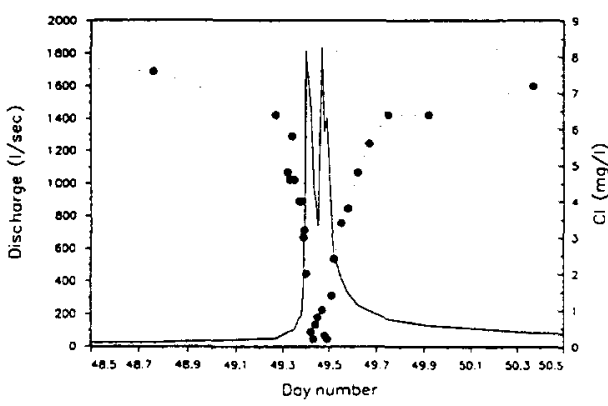

Cully A

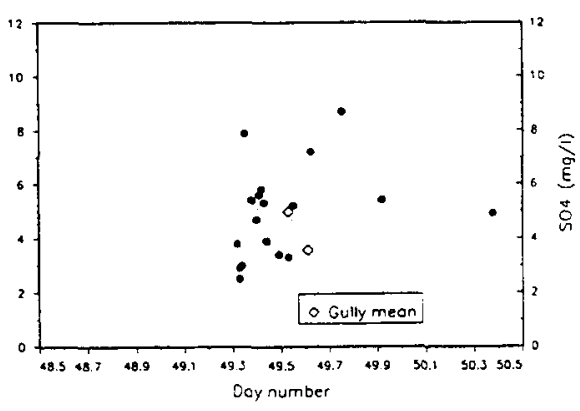

Guliy 8



South Creek

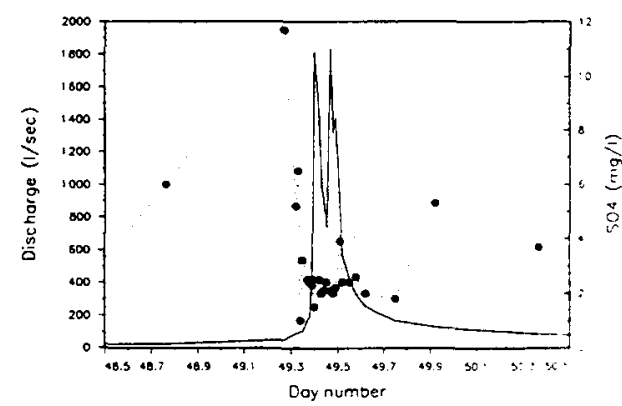

Fig. 6. South Creek discharge (solid line, bottom), and chloride and sulfate concentration in gully $A$ (top). gully B (middle) and South Creek (bottom) during event 1 . The open symbol in the top panels represents the mean value of gullies $\mathrm{C}, \mathrm{D}$ and $\mathrm{E}$.

Fig. 6 displays the behavior of two anions, chloride and sulfate. Unlike in other situations where stream $\mathrm{Cl}$ concentrations increase with discharge, either due to Cl-rich precipitation (e.g. Mulder et al., 1990), or due to enrichment in the soil as a result of prolonged dry periods (Avila et al., 1992), they decrease in this environment. Except for early in the event, the 'new' water, i.e. gully $\mathrm{A}$, is very low in $\mathrm{Cl}$, although a drastic, and as yet unexplained, increase in $\mathrm{Cl}$ levels in overland flow during the recession is observed. As to sulfate, the wildly fluctuating values hamper a straightforward interpretation. Nonetheless, a dilution effect is obvious for South 
Creek, similar to observations made by Whitfield et al. (1993), but in contrast to those made by Avila et al. (1992). The flushing effect in overland flow mentioned previously, as evidenced by an initial increase and a subsequent pronounced decrease, may be postulated for sulfate as well. In contrast to other elements, this effect is obvious even in gully $\mathbf{B}$.

To summarize event 1 , the stormflow $\mathrm{pH}$ variation in South Creek is minor, the $\mathrm{K}$ increase with discharge is pronounced, and all other quantities are diluted during stormflow. This pattern is consistent with the premise that 'new' water, i.e. overland flow (represented by gully A) dominates the stormflow hydrograph, but cannot be explained by an 'old' water-dominated stormflow hydrograph. An 'old' water contribution is not necessarily associated with a 'slow' pathway (McDonnell, 1990); 'new' water, in contrast, implies a 'fast' pathway, such as overland flow. This pathway had been postulated previously (Bonell and Gilmour, 1978), based on actual measurements and on soil physical and meteorological grounds, and the solute behavior during event 1 supports this earlier conclusion. Gullies C, D and E (see Fig. 1) were sampled occasionally and the results are plotted as a mean value in the respective graphs with the same, but open, symbol. The top graphs in Fig. 2 provide an example. The concentrations of all four species, expressed as the arithmetic mean of gullies $\mathrm{C}, \mathrm{D}$ and $\mathrm{E}$, are lower than those in gully $\mathrm{A}$. This result may merely reflect the spatial variability of the chemical composition of overland flow. However, gullies $\mathrm{C}, \mathrm{D}$ and $\mathrm{E}$ are, in contrast to gully $\mathrm{A}$, hardly incised; concentrated-flow line, or perhaps rill, would be technically a more appropriate description. Due to its incision, gully $A$ is capable of draining any water table that is higher than its talweg. Such 'perched' water tables may develop temporarily if and when rainfall intensities exceed the soil hydraulic conductivity at some depth. This mechanism has been documented in detail for the South Creek catchment (Bonell et al., 1981); however, it is not a peculiarity of this environment (Elsenbeer and Cassel, 1991). Also, upward soil water fluxes were observed during storm events (Bonell et al., 1981). The depth of incision of gully $A$ is, along most of its reach, deeper than the expected depth of such a perched water table. Consequently, lateral drainage towards gully $\mathrm{A}$ is conceivable, although at which point during an event such a drainage begins to contribute appreciably to the flow in gully $\mathrm{A}$ cannot be determined without relevant hydrometric measurements; this subsurface flow may not even show up as 'overland flow' in gully $A$ until true overland flow has ceased. Hence, the difference in the concentrations between gullies $C, D$ and $E$, and gully $A$ may reflect not only spatial variability of overland flow chemistry, but also the contribution of subsurface stormflow, chemically distinct on account of its different flowpath. In other words, gully A may contribute, presumably later during an event, or after precipitation ceases, also subsurface stormflow which, on account of its pathway through upper soil horizons, is chemically distinct from overland flow.

\subsection{Event $2-23$ February $1993,44.2 \mathrm{~mm}$ rain in $3 \mathrm{~h}$}

This event is quite distinct from the previous one in several respects (see Table 2 for rainfall details). Firstly, its peakflow amounted to $404 \mathrm{~L} \mathrm{~s}^{-1}$, as opposed to $1841 \mathrm{~L} \mathrm{~s}^{-1}$ 
GullyA

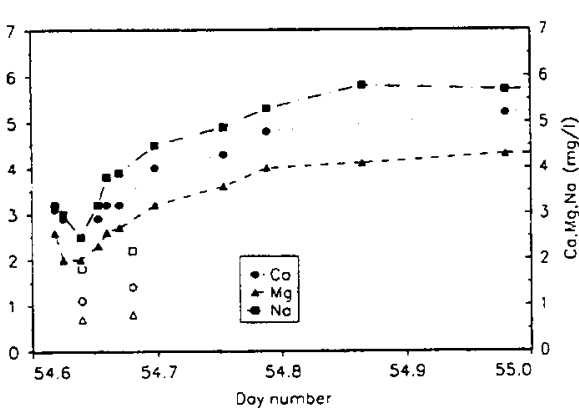

Gully $B$

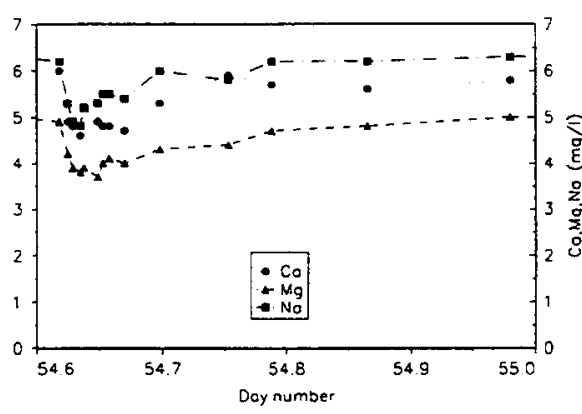

South Creek

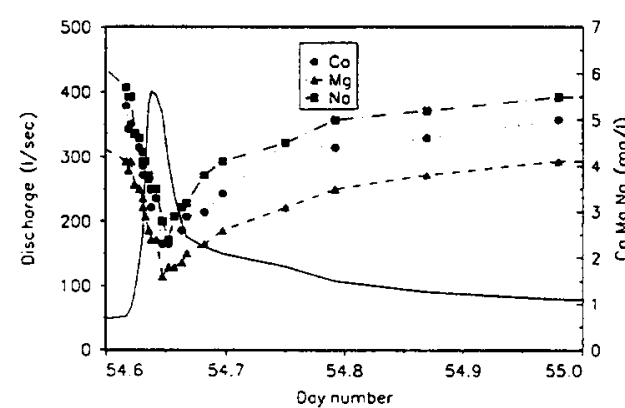

Gullya

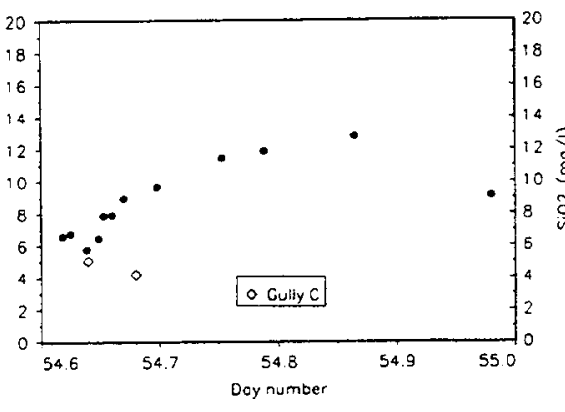

Gully $B$

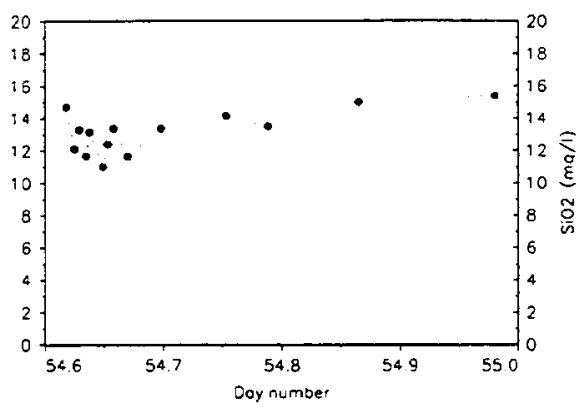

South Creek



Fig. 7. South Creek discharge (solid line, bottom), and calcium, magnesium, sodium and silica concentration in gully A (top), gully B (middle) and South Creek (bottom) during event 2.

of event 1 . Secondly, only 5 days had passed since the previous major event, i.e. event 1 , as opposed to 14 days which preceded event 1 without a major precipitation event. That is to say, the antecedent moisture conditions were obviously quite different for the two events, as were their total flows.

Fig. 7 shows the $\mathrm{Ca}, \mathrm{Mg}, \mathrm{Na}$ and $\mathrm{SiO}_{2}$ pattern during event 2 . The dilution of these solutes in South Creek and their recovery is similar to event 1 . What is remarkably different, however, is the pattern in gully $\mathbf{A}$. The dilution so obvious during event 1 (Fig. 2) is barely discernible in the course of this event. Also, the initial solute concentrations are considerably lower. The increase in concentration, as flow in 
gully A gradually decreases, to levels higher than at the onset of the event can be explained only if one accepts that flow in gully $A$ in the wake of an event consists mainly of subsurface stormflow. That a situation generating subsurface stormflow arises rather quickly during event 2 is plausible in view of the antecedent moisture conditions. As before, an independent check of overland flow chemistry was obtained, but only for gully C. The top panel of Fig. 7 shows solute concentrations much lower in samples from a non-incised concentrated-flow line (gully $\mathrm{C}$, open symbols) than in samples from a gully sensu strictu (gully A, closed symbols). Again, this supports the interpretation that gully A transfers subsurface stormflow in addition to true overland flow, with subsurface stormflow prevailing during the recession. The effect of event 2 on the solute behavior in gully B (Fig. 7) is minor compared to event 1 (Fig. 2), indicating even less overland flow contribution to gully $B$.

The $\mathrm{K}$ pattern in South Creek (Fig. 8, bottom panel) is identical to event 1 (Fig. 3, bottom panel): concentration increases with flow, the peak concentration occurs after the stormflow peak. The peak concentration in this storm is considerably lower than in the previous one. The pattern in gully A (Fig. 8, top panel) differs from event 1 (Fig. 3, top panel) in that the initial flushing effect observed during the previous event is absent. The peak levels are roughly identical on both occasions. During both events the samples from other gullies (see open symbols in Fig. 3 for event 1 and in Fig. 8 for event 2) contain higher $\mathrm{K}$ levels than the respective samples from gully $\mathrm{A}$. This observation lends further support to the idea that gully A drains, during the recession, a hydrologic compartment the chemical signature of which is distinct from overland flow. In gully $\mathrm{B}$ (Fig. 8), the increase in $\mathrm{K}$ is almost negligible compared to event 1 (Fig. 3); the contribution of overland flow in its subcatchment was minor. The patterns of behavior of $\mathrm{K}$ are similar in both events. Quantitative differences can be attributed to the hydrometeorologic differences between the two events, most noticeably their magnitudes, their antecedent dry periods and maximum intensities (Table 2). The $\mathrm{K}$ signal in stormflow might be dampened successively as the antecedent dry periods get shorter with the progressing wet season. If the observations made in western Amazonia by the senior author are any indication, stormflow $\mathrm{K}$ chemographs independent of discharge are to be expected with increasing frequency of precipitation. Such 'flat' $\mathrm{K}$ chemographs have also been observed in a boreal wetland catchment (Hill, 1993). It is concluded that $\mathrm{K}$ is a useful, if seasonally dependent, indicator of 'new' water.

The $\mathrm{pH}$ depression in South Creek associated with event 2 (Fig. 8, left-hand panels) is less than one unit, similar to event 1 (Fig. 3). In contrast to event 1 , when the $\mathrm{pH}$ dropped ever so slightly, it remained unchanged in both gully $\mathrm{A}$ and gully $\mathrm{B}$ during event 2. The drop in $\mathrm{pH}$ in South Creek, though not tied to the pattern in gully $\mathrm{A}$, may still be attributed to overland flow by noting that the lowest $\mathrm{pH}$ approaches that of gully C (Fig. 8, left-hand top panel, open symbol).

The pattern of EC and ANC (Fig. 9) and of alkalinity and total inorganic carbon (Fig. 10) reflects that of cations and $\mathrm{SiO}_{2}$; it can be interpreted accordingly. While the stormflow patterns of these four quantities differ from event 1 (see Figs. 4 and 5) only in respect of the lowest concentrations attained, the pattern in gully $A$ (see respective 

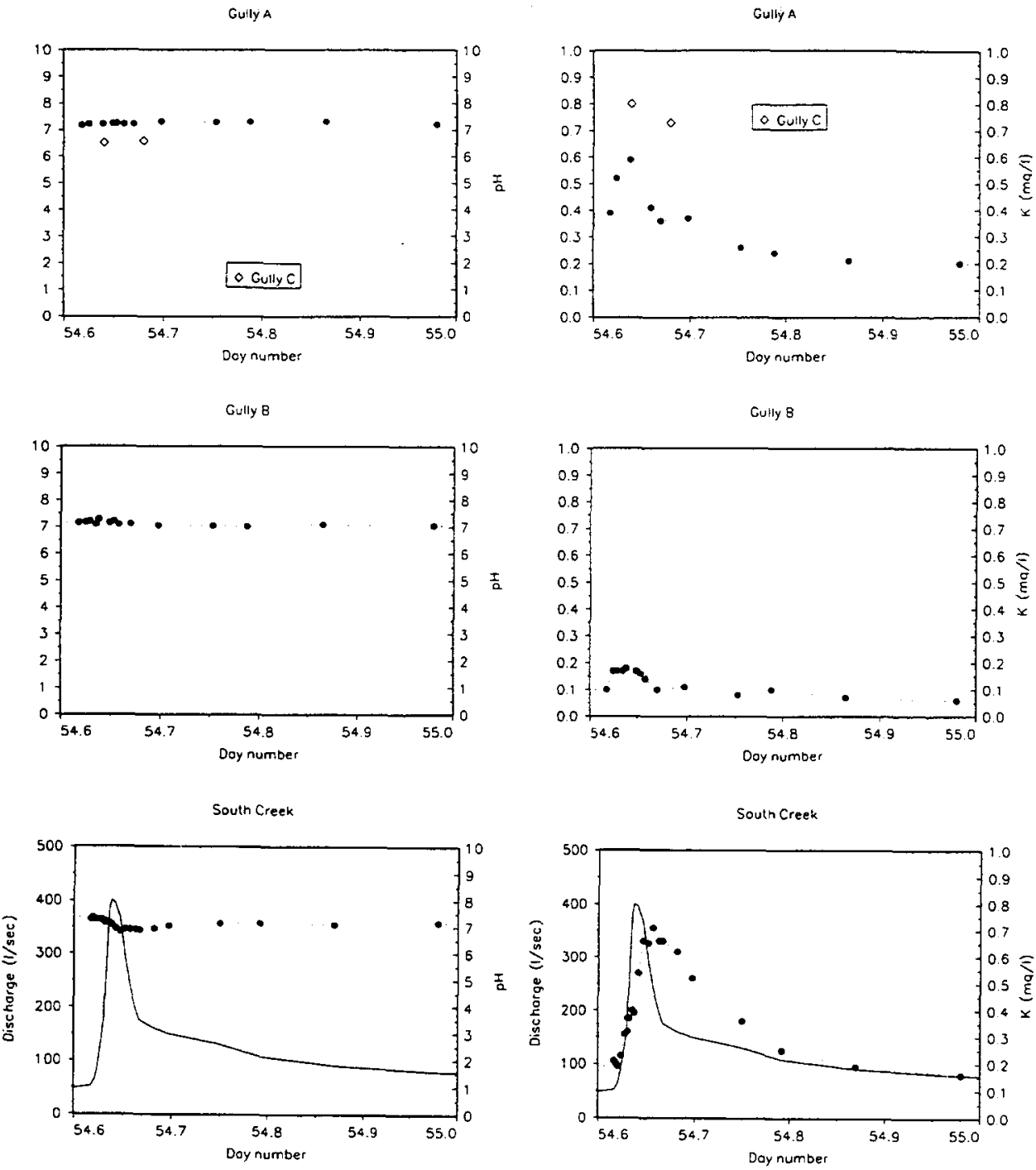

Fig. 8. South Creek discharge (solid line, bottom), $\mathrm{pH}$ and potassium concentration in gully A (top), gully B (middle) and South Creek (bottom) during event 2.

top panels) is quite distinct from event 1 . The decrease in these quantities is minor, and the subsequent recovery exceeds the initial levels significantly, as well as the corresponding levels in South Creek. Most obvious, however, is the discrepancy between the respective levels in gully $A$ and in gully $C$. In accordance with the discussion of event 1 , this constitutes prima-facie evidence that, in this event, preceded only 5 days earlier by a $177.7 \mathrm{~mm}$ rainfall, the runoff in gully $\mathrm{A}$ consists to a considerable extent of subsurface stormflow, derived from upper soil horizons, above the 'hydrologic throttle' (Bonell and Balek, 1993, p. 215), although deeper layers may also have contributed in this event by means of flux reversal 
Gully A

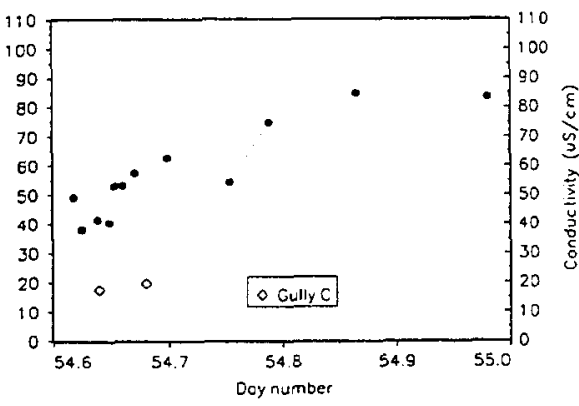

Gullye

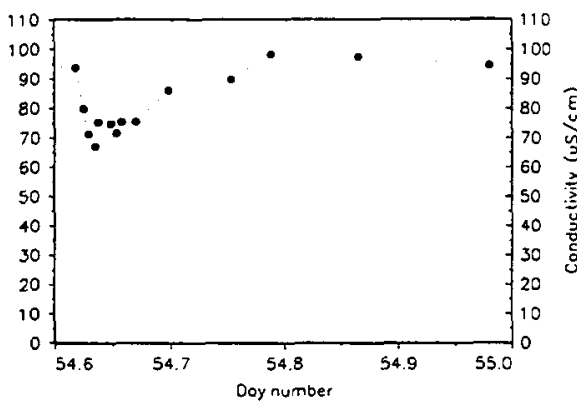

South Creek



Guilya

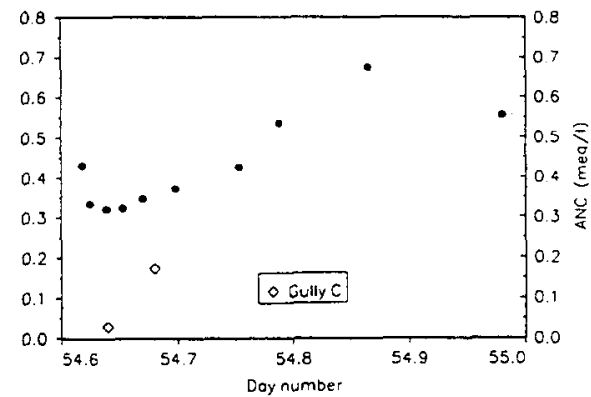

Gully B

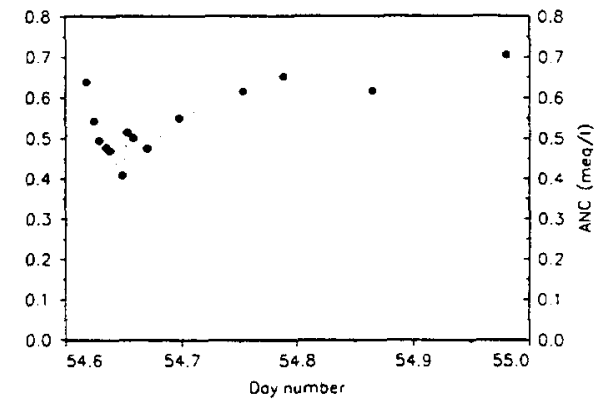

South Creek

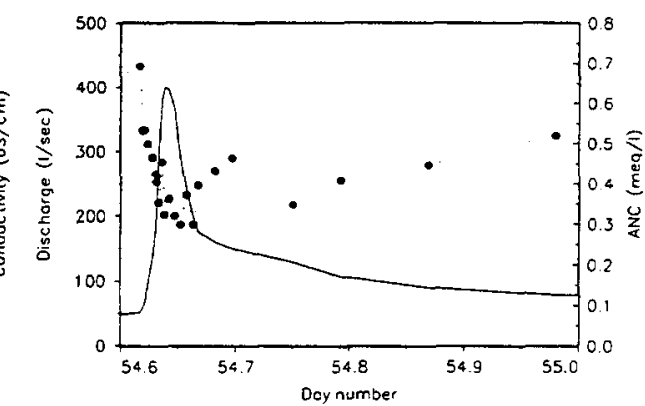

Fig. 9. South Creek discharge (solid line, bottom), and electric conductivity and acid neutralizing capacity in gully A (top), gully B (middle) and South Creek (bottom) during event 2.

(Bonell et al., 1984). These layers are more likely to contribute as the dry periods between events decrease.

The $\mathrm{Cl}$ pattern in South Creek (Fig. 11) follows that of event 1 (Fig. 6), whereas the minor dilution in gully $\mathbf{A}$ is followed by an increase to levels similar to those in gully $\mathbf{B}$ and South Creek. The lowest level in South Creek, attained shortly after peakflow, corresponds to that of gully $\mathrm{C}$, rather than gully $\mathrm{A}$, in support of the runoff in gully $\mathrm{A}$ being composed of subsurface stormflow in addition to overland flow.

As in the case of event 1 , the interpretation of the sulfate pattern is hampered by erratic trends. The initial increase in South Creek evident during event 1 (Fig. 6) 
Guily A

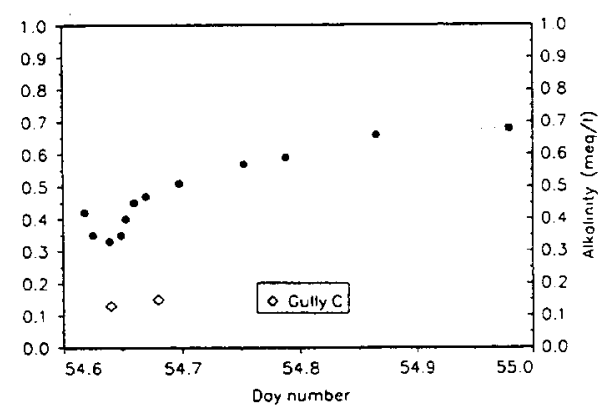

Gully E

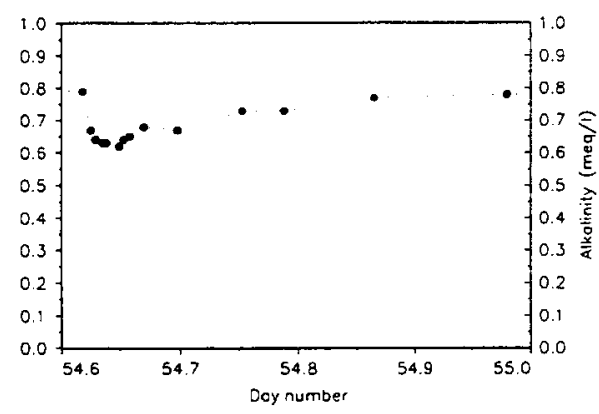

South Creek

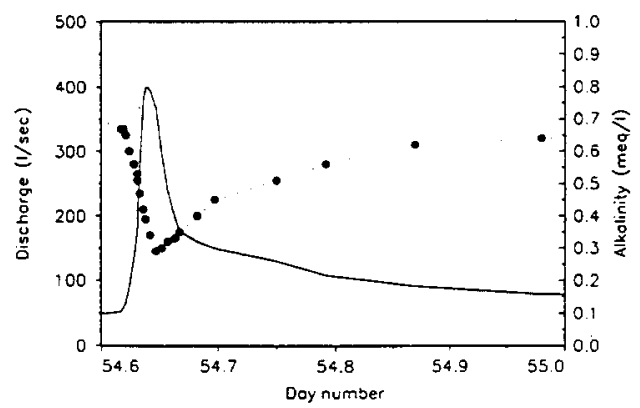

Gullya

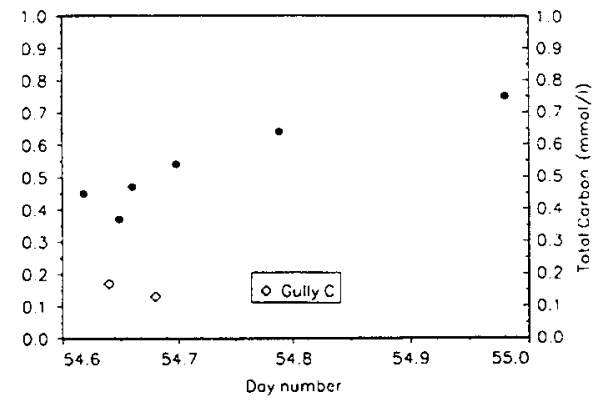

Guily 9



South Creek

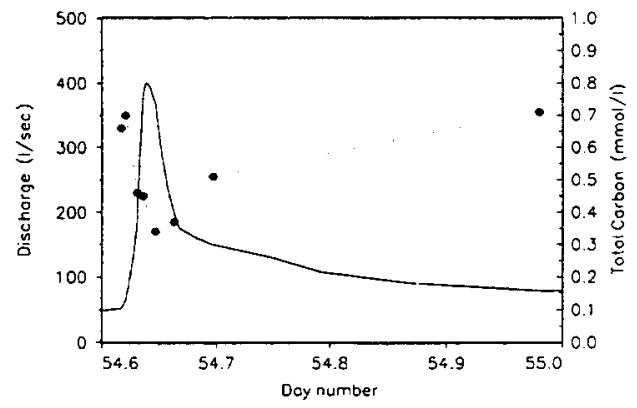

Fig. 10. South Creek discharge (solid line, bottom), and alkalinity and total inorganic carbon concentrations in gully A (top), gully B (middle) and South Creek (bottom) during event 2.

is repeated during event 2 (Fig. 11). In contrast to $\mathrm{K}$, the peak concentrations of sulfate seem to precede the hydrograph peak. The sulfate pattern in gully A (Fig. 11) differs from event 1 (Fig. 6) in that a steady increase is observed from the beginning of the event; the initial peak observed during event 1 is absent. An initial, brief sulfate flush during stormflow was earlier attributed to a similar signal in overland flow, then quite obvious in gully A (Fig. 6); during event 2 , this signal is more obvious from gully $C$ data points. The initial increase in sulfate observed in gully B during event 1 (Fig. 6) is repeated in event 2 (Fig. 11). 

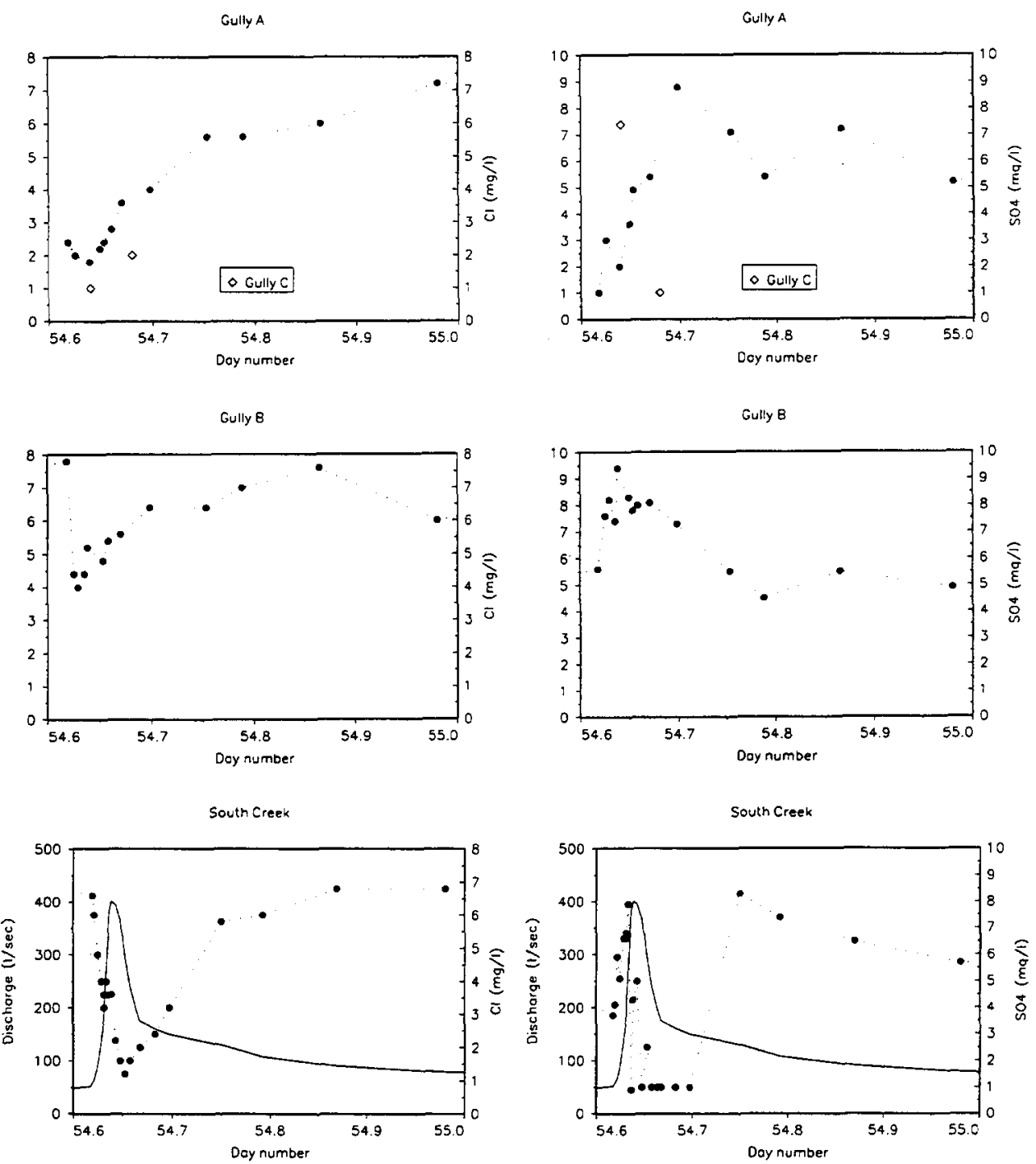

Fig. 11. South Creek discharge (solid line, bottom), and chloride and sulfate concentration in gully A (top), gully B (middle) and South Creek (bottom) during event 2.

To summarize event 2, the stormflow patterns of all quantities in South Creek are similar to their respective patterns during event 1: a pronounced dilution occurs for all quantities except for $\mathbf{K}$ and sulfate. The dilution is smaller than in event 1 , which reflects the distinct rainfall characteristics of the two events (Table 2). The patterns in gully A differ markedly from event 1 , and can be explained only if a source in addition to overland flow is postulated. This conclusion is further supported by the pronounced concentration differences in gully $\mathrm{A}$ and gully $\mathrm{C}$, in comparison to the previous event. As a result, the chemical signature of gully $\mathrm{A}$ is less useful in explaining the stormflow chemistry of South Creek for this event than it was 
for the previous one. It points, however, to the importance of flowpaths other than overland flow, in particular during streamflow recession, and to the dependence of flowpaths on hydrometeorologic conditions. Given the consistent chemograph patterns in South Creek and the additional information from gully $\mathrm{C}$, the importance of overland flow as a hydrologic pathway providing 'new' water during storm events must be reiterated.

\section{Conclusions}

The observed stormflow patterns of selected chemical quantities in South Creek are consistent with a major contribution of 'new' water; they were confirmed by sampling the 'new' water directly. The 'new' water chemistry itself shows a distinct temporal pattern; hence, the stormflow pattern reflects not only the varying degree of mixing of 'old' and 'new' water during an event, but also that temporal variation in 'new' water is itself event-dependent due to different hydrometeorologic conditions. Where overland flow occurs in a localized fashion, the site selection for sampling is crucial to the interpretation of its solute chemistry. With increasing catchment wetness, the more incised pathways acquire a hydrochemical fingerprint different from that of 'pure' overland flow, as determined during relatively dry conditions and/or from non-incised pathways. This study also supports a combined hydrologic-hydrochemical approach: whenever possible, pathways should be identified by independent means, instead of merely being inferred. Last, but not least, the assumption of temporal invariance of one or several end members, common in mixing models, is difficult to support.

\section{Acknowledgments}

This project was funded by the Swiss National Science Foundation which also provided support for Adam West and Mike Bonell. Karin Bryant, Daniel Lorieri and Dagmar Riesen assisted in the collection and field analysis of water samples. Barry Butler and John Faithful (Australian Centre for Tropical Freshwater Research) generously supported our field analytical efforts. Clive Grant provided the streamflow and precipitation records.

\section{References}

APHA, 1989. Standard Methods for the Examination of Water and Wastewater, 17th edn. American Public Health Association, Washington, DC.

Avila, A., Piñol, J., Rodà, F. and Neal, C., 1992. Storm solute behaviour in a montane Mediterranean forested catchment. J. Hydrol., 140: 143-161.

Beck, M.B., Kleissen, F.M. and Wheater, H.S., 1990. Identifying flow paths in models of surface water acidification. Rev. Geophys., 28: 207-230. 
Bonell, M. and Balek, J., 1993. Recent scientific developments and research needs in hydrological processes of the humid tropics. In: M. Bonell, M.M. Hufschmidt and J.S. Gladwell (Editors), Hydrology and Water Management in the Humid Tropics. Cambridge University Press, Cambridge, $624 \mathrm{pp}$.

Bonell, M. and Gilmour, D.A., 1978. The development of overland flow in a tropical rainforest catchment. J. Hydrol., 39: 365-382.

Bonell, M. and Gilmour, D.A., 1980. Variations in short-term rainfall intensity in relation to synoptic climatological aspects of the humid tropical north-east Queensland coast. Singapore J. Trop. Geog., 1: $16-30$.

Bonell, M., Gilmour, D.A. and Sinclair, D.F., 1981. Soil hydraulic properties and their effect on surface and subsurface water transfer in a tropical rainforest catchment. Hydrol. Sci. Bull., 26: 1-18.

Bonell, M., Cassels, D.S. and Gilmour, D.A., 1984. Vertical soil water movement in a tropical rainforest catchment in north-east Queensland. Earth Surf. Processes Landforms, 8: 253-272.

Bonell, M., Gilmour, D.A. and Cassells, D.S., 1991. The links between synoptic climatology and the runoff response of rainforest catchments on the wet tropical coast of north eastern Queensland. In: P.A. Kershaw and G. Werran (Editors), Australian National Rainforests - Study Report Vol. 2. Australian Heritage Commission, Canberra, pp. 27-62.

Elsenbeer, H. and Cassel, D.K., 1989. Flow generation mechanisms and water chemistry in a tropical rainforest catchment. Chapman Conference on Hydrological Responses of Forested Catchments. Bar Harbor, Maine, 18-21 September 1989.

Elsenbeer, H. and Cassel, D.K., 1991. The mechanisms of overland flow generation in a small catchment in western Amazonia. In: B.P.F. Braga and C.A. Fernández-Jáuregui (Editors), Water Management of the Amazon Basin. UNESCO, Montevideo, Uruguay, pp. 213-220.

Feller, M.C. and Kimmins, J.P., 1979. Chemical characteristics of small streams near Haney in southwestern British Columbia. Water Resour. Res., 15: 247-258.

Giusti, L. and Neal, C., 1993. Hydrological pathways and solute chemistry of storm runoff at Dargall Lane, southwest Scotland. J. Hydrol., 142: 1-27.

Harriman, R., Gillespie, E., King, D., Watt, A.W., Christie, A.E.G., Cowan, A.A. and Edwards, T., 1990 Short-term ionic responses as indicators of hydrochemical processes in the Allt $A^{\prime}$ Mharcaidh catchment, western Cairngorms, Scotland. J. Hydrol., 116: 267-285.

Hill, A.R., 1993. Base cation chemistry of storm runoff in a forested headwater wetland. Water Resour Res., 29: 2663-2673.

Jenkins, A., 1989. Storm period hydrochemical response in an unforested Scottish catchment. Hydrol. Sci. J., 34: 393-404.

McDonnell, J.J., 1990. A rationale for old water discharge through macropores in a steep, humid catchment. Water Resour. Res., 26: 2821-2832.

Miller, R.W. and Drever, J.I., 1977. Water chemistry of a small stream following a storm, Absaroka Mountains, Wyoming. Geol. Soc. Am. Bull., 88: 286-290.

Mulder, J., Christophersen, N., Hauhs, M., Vogt, R.D., Andersen, S. and Andersen, D.A., 1990. Water flow paths and hydrochemical controls in the Birkenes catchment as inferred from a rainstorm high in seasalts. Water Resour. Res., 26: 611-622.

Mulholland, P.J., Wilson, G.V. and Jardine, P.M., 1990. Hydrogeochemical response of a forested watershed to storms: effects of preferential flow along shallow and deep pathways. Water Resour. Res., 26: 3021-3036.

Muscutt, A.D., Wheater, H.S. and Reynolds, B., 1990. Stormflow hydrochemistry of a small Welsh upland catchment. J. Hydrol., 116: 239-249.

Robson, A., Neal, C., Smith, C.J. and Hill, S., 1992. Short-term variations in rain and stream water conductivity at a forested site in mid-Wales - implications for water movement. Sci. Tot. Environ., 119: 1-18.

Wels, C., Cornett, R.J. and Lazerte, B.D., 1991. Hydrograph separation: a comparison of geochemical and isotopic tracers. J. Hydrol, 122: 253-274.

Whitfield, P.H., Rousseau, N. and Michnowsky, E., 1993. Rainfall induced changes in chemistry of a British Columbia coastal stream. Northwest Sci., 67: 1-6. 
Wilson, G.V., Jardine, P.M., Luxmoore, R.J., Zelazny, L.W., Lietzke, D.A. and Todd, D.E., 1991a. Hydrochemical processes controlling subsurface transport from an upper subcatchment of Walker Branch watershed during storm events. 1. Hydrologic transport processes. J. Hydrol., 123: 297-316.

Wilson, G.V., Jardine, P.M., Luxmoore, R.J., Zelazny, L.W., Todd, D.E. and Lietzke, D.A., 1991b. Hydrochemical processes controlling subsurface transport from an upper subcatchment of Walker Branch watershed during storm events. 2. Solute transport processes. J. Hydrol., 123: 317-336. 